Nipawin: Rather rare summer resident. Noted locally on the east side of the Saskatchewan River, from Nipawin South to the Nipawin Rapids, during nine of the past fourteen summers. A nest with four eggs was found at the end of a spruce bough 20 feet from the ground, half a mile south of Nipawin Union Hospital on July 1, 1945. After the young had left, the nest was collected by Fred G. Bard of the Saskatchewan Museum of Natural History, Regina (Can. Field-Nat., 61:67, 1947). Matthews once saw one at their farm, a little over a mile east of the river, and an adult was seen on one ocrasion at the writer's residence, in Nipawin, Sept. 3, 1954. (Street).

The most recent report from northern Saskatchewan is that given by $R$. W. Nero in Birds of the Lake Athabasca Region, Saskatichewan (1963). A pair, apparently breeding, was seen at Carswell Lake, south of Lake Athabasca, on July 14, 1962.

All of the above records are either within or on the fringe of the Canadian zone where it appears that the bird is a rare summer resident. Birds that migrate to central Saskatchewan undoubtedly pass through the transition zone; it may be that the birds pass quickly over the south and rarely stop unless forced down by extreme weather conditions. Whatever the explanation, I have been able to find only a very few records for the southern (transition) zone of the province. In correspondence with Steve. Mann recently I learned that he saw what he is reasonably sure was a Western Tanager near his home at Skull Creek in the fall of 1917. The other sight records for southern Saskatchewan belong to the years 1961 and 1962 , with the Broadview specimen record for 1963 . In 1961 an observation was submitted to Audubon Field Notes (15:421) from Estevan [one seen by Ross Lein, May 21, 1961l, and for 1962 Audubon Field Notes $(16: 426)$ reported one male at Regina "seen by at least two observers" on May 18, and observations in Moose Jaw on May 22 and May 28. Because of the scarcity of previous records for the southern part of the province, and because the 1961-62 records were sight observations by amateur observers, the 1963 specimen record from Broadview is of particular importance.

\section{CHANGES IN THE NEST SITE OF THE HOUSE SPARROW}

\author{
by John Lane, Brandon
}

In setting out nest boxes for Tree Swallows and bluebirds, our Brandon Junior Birders are faced with the problem of competition from House Sparrows for nest sites. From our four years of experience, we have learned a lot about where or where not to set up nest boxes. However, when changes in habitat cause House Sparrows to move, the Junior Birders often find that their carefully-placed nest boxes are once again taken over by House Sparrows.

A case in point was the tearing down of the huge CPR coal dock at Broadview. Readers who are acquainted with this type of structure will know what a haven they were for sparrows, with countless nooks and crannies in. which they could build their nests. When the Broadview dock was torn down, I found House Sparrows in possession of our nest boxes half a mile, one mile, and two miles east of Broadview. All these nest boxes had housed Mountain Bluebirds in 1962, so it was a real blow to find House Sparrows in possession.

On farms, too, the disappearance of old barns is forcing House Sparrows to seek new nest sites. During the winter of 1961-62 the Brandon Junior Birders received permission to set out a series of nest boxes on the J. Friesen farm, one and one-half miles west of Griswold, Manitoba. The results in 1962 were entirely successful: in the 12 boxes that were put out, 11 pairs of Tree Swallows and one pair of Mountain Bluebirds nested. This spring the Friesens tore down their old cattle barn, thus depriving the local tribe of House Sparrows of their long-time nesting site. When we checked this summer, we found that no less than nine pairs of House Sparrows had moved from the farmstead and taken up residence in our nest boxes. Only one pair of Tree Swallows had survived the invasion, and two nest boxes were missing, probably knocked down by cattle. It was necessary to rebuild two and move 11 to new localities in a renewed attempt to escape the sparrows. 